\title{
Freshwater fish species richness and conservation of mountain streams in the Jinggang- shan National Nature Reserve, China
}

\author{
Maolin Hu, Huiming Zhou, Zhiqiang Wu, Shan Ouyang \& Chunquan Chen
}

Keywords: freshwater fish, composition, distribution, conservation, mountain streams, Jinggangshan National Nature Reserve

\section{Abstract}

Jinggangshan National Nature Reserve is located in the middle reach of the Luoxiao Mountains in the south-western Jiangxi Province. The fish fauna of mountain streams in the nature reserve was investigated seasonally during 2011. A total of 553 samples were collected and classified into 12 families and 38 species. The samples collected in the nature reserve did not include any exotic species. The most abundant fish species collected was Pseudogastromyzon changtingensis tungpeiensis, followed by Acrossocheilus parallens, Rhinogobius cliffordpopei and Rhinogobius giurinus. A total of 16 species were found to be endemic to China. Current threats to the conservation of fishes in the nature reserve were reviewed and management solutions were suggested.
Profile

Protected area

Jinggangshan National Nature

Reserve

Mountain range

Luoxiao Mountains

Country

China

\section{Introduction}

Jiangxi Province (between 24⒉ 29' 14" - 30 04' 41" N and $113^{\circ} 34^{\prime} 36^{\prime \prime}-118^{\circ} 28^{\prime} 36^{\prime \prime} \mathrm{E}$ ) is located in southern China, and south of the middle and lower reaches of the Yangtze River. Poyang Lake, the largest freshwater body in China, is located in the north of Jiangxi Province. The area immediately surrounding Poyang Lake consists of low-lying alluvial plains prone to flooding. Mountains close to the boundaries of Jiangxi Province surround this region and all the five major rivers in the province (Ganjiang, Xinjiang, Fuhe, Raohe and Xiuhe) flow into Poyang Lake. The drainage to Poyang Lake is a narrow outlet named Hukou, which flows into the Yangtze River and marks the northern border of the province. The sources of the rivers in Jiangxi Province are located in the surrounding mountains. Of a total of 220 recorded freshwater fish species throughout Jiangxi Province, about 131 species (59.5\%) are believed to be endemic, many present in the mountainous regions (Huang et al. 2011). Protected areas such as nature reserves could play an important role in the conservation of freshwater fishes within Jiangxi Province, but there is a need to better identify the conservation value of these areas in relation to the biogeographical diversity of fishes and the factors impacting on fish communities.

Worldwide, freshwater fishes are the most diverse of all vertebrate groups, but are also the most threatened group of vertebrates after amphibians (Moyle \& Leidy 1992; Bruton 1995; Duncan \& Lockwood 2001). Most mountain streams in Jinggangshan National Nature Reserve (JNNR) are shallow and the hydrology of most headwater streams has been modified by farming and irrigation of the surrounding land. Recently, nu-

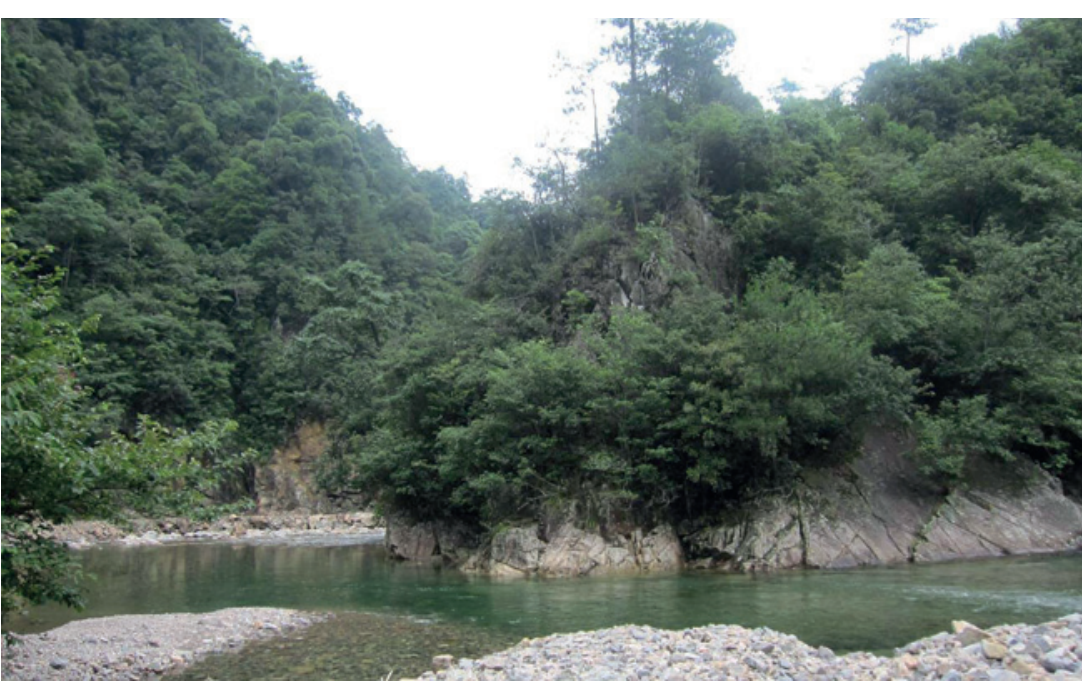

Figure 1 - Mountain stream in the Jinggangshan National Nature Reserve. (C) M. Hu

merous anthropogenic disturbances, such as clearings, small dams, road construction, fires and mining, have triggered physico-chemical alterations in the mountain streams (Lin 1990).

At present there have been several notable surveys of the flora and fauna within the nature reserve. (Deng et al. 2003; Xiao et al. 2004; Li et al. 2005; Huang et al. 2007a,b; Deng et al. 2008; Long et al. 2008; Zuo et al. 2008; Cheng et al. 2011). However, prior to this work there were no studies on the distribution and abundance of fish species in the nature reserve. The aims of the present study are: (1) to characterize the species composition of the fish fauna and their distribution in the nature reserve; (2) to review the main threats over fish biodiversity, and (3): to establish some recommendations to the conservation of the fish fauna. 


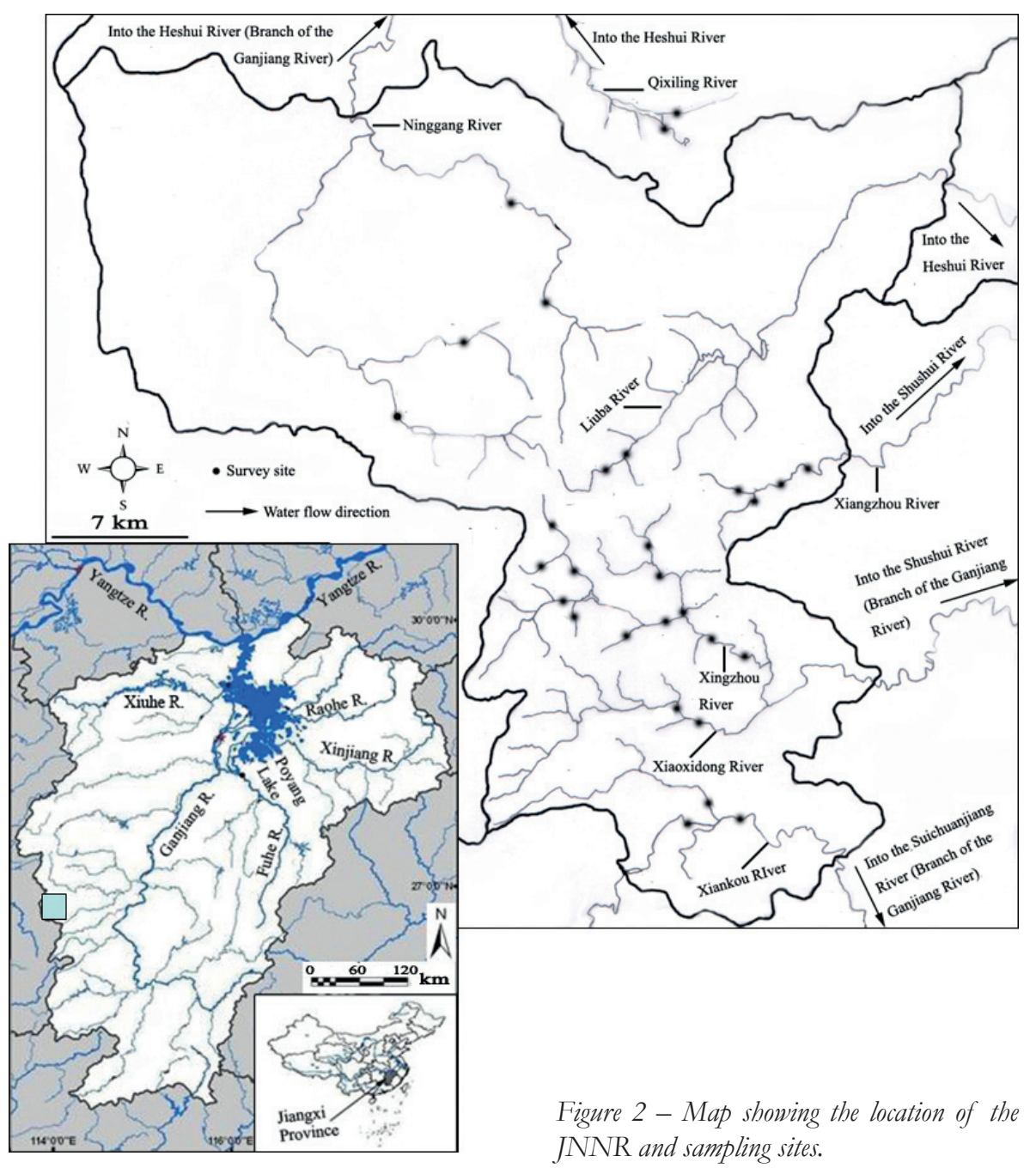

JNNR and sampling sites.

\section{Materials and Methods}

Study area

The JNNR (total area: $214.99 \mathrm{~km}^{2}$, altitude: $1600 \mathrm{~m}$, between $26^{\circ} 38^{\prime} 39^{\prime \prime}-26^{\circ} 40^{\prime} 03^{\prime \prime} \mathrm{N}$ and $114^{\circ} 04^{\prime} 05^{\prime \prime}-114^{\circ} 16^{\prime} 38^{\prime \prime} \mathrm{E}$ ) is located in the middle reach of the Luoxiao Mountains in the south-western Jiangxi Province (Figure 2). The nature reserve has humid subtropical climate and belongs to the forestecological nature reserve for the conservation of evergreen broad-leaved forest ecological systems and biodiversity. Annual precipitation is $1865.5 \mathrm{~mm}$, annual temperature ranges from $14^{\circ} \mathrm{C}$ to $17^{\circ} \mathrm{C}$, and forests cover up to $95.5 \%$ of the land ( $\operatorname{Lin} 1990)$ ). Most mountain streams in the nature reserve flow into the Heshui River, Shushui River and Suichuanjiang River, which drain into the Ganjiang River (Figure 1).

\section{Study sites}

Twenty-nine sites were established on mountain streams in JNNR (Figure 1). Sampling site selections were based on the representative habitat types present and accessibility during the study period. At each sampling site, the GPS position and altitude were recorded using a Garmin GPS map 76Cx. And water tempera- ture and dissolved oxygen were measured with a handheld YSI multi-meter. In addition, stream width and water depth were measured at each site.

\section{Fish survey}

Samples were taken seasonally at twenty-nine sites in the JNNR. All the stations were characterized by shallow water depths, narrow channel widths and relatively fast currents flowing over boulder substrate. At each site, samples were collected using an electrofishing device consisting of two copper electrodes on wooden handles, powered by a 500 watt portable AC generator. Stunned fish were collected using dip nets or caught by hand. A cast net (mesh $5 \times 5 \mathrm{~mm}^{2}$; $\pi \times 0.6^{2} \mathrm{~m}=1.13 \mathrm{~m}^{2}$ ) was also used in shallow pools of the stream system to collect fish. Approximately $100 \mathrm{~m}$ of a stream segment, typically comprising pool, run and riffle habitats, was sampled at each site. Collected specimens that could not be identified in the field were fixed in 10\% formalin solution for accurate taxonomic verification. All specimens were identified according to Zhu (1995), Chen (1998), Chu et al. (1999) and Yue (2000). 
Table 1 - Characteristics of the sampled rivers in the JNNR, including altitude, number of sampling sites, stream width and water depth, and habitat types.

\begin{tabular}{|l|r|r|r|r|l|}
\hline Studied river & Altitude [m] & Depth [m] & Width [m] & No. sites surveyed & Habitat description \\
\hline Qixiling River & $300-355$ & $0.3-0.6$ & $2.0-4.0$ & 2 & $\begin{array}{l}\text { Slow flowing and clear water with gravel and sandy sub- } \\
\text { strate, river shaded by riparian vegetation }\end{array}$ \\
\hline Ninggang River & $260-560$ & $0.1-0.5$ & $1.0-6.0$ & 4 & $\begin{array}{l}\text { Slow flowing and slightly turbid water, rocky and sandy } \\
\text { bottom, shaded by riparian vegetation }\end{array}$ \\
\hline Liuba River & $440-500$ & $0.1-0.8$ & $2.0-5.0$ & 2 & $\begin{array}{l}\text { Fast flowing and slightly turbid water with rocky and sandy } \\
\text { substrate, partially shaded by forest canopy and riparian } \\
\text { vegetation }\end{array}$ \\
\hline Xiangzhou River & $325-380$ & $0.5-0.8$ & $5.0-7.0$ & 4 & $\begin{array}{l}\text { Slow flowing and clear water with rocky and sandy sub- } \\
\text { strate, shaded by forest canopy }\end{array}$ \\
\hline Xingzhou River & $315-910$ & $0.1-1.2$ & $1.0-10.0$ & 12 & $\begin{array}{l}\text { Fast flowing and clear water with rocky, gravel and sandy } \\
\text { substrate, shaded by forest canopy }\end{array}$ \\
\hline Xiaoxidong River & $320-350$ & $0.2-1.0$ & $1.5-7.0$ & $2 \begin{array}{l}\text { Slow flowing and clear water with rocky and sandy sub- } \\
\text { strate, shaded by riparian vegetation }\end{array}$ \\
\hline Xiankou River & $210-265$ & $0.2-0.8$ & $6.0-12.0$ & 3 & $\begin{array}{l}\text { Slow flowing and slightly turbid water with rocky, gravel } \\
\text { and sandy bottom, shaded by riparian vegetation }\end{array}$ \\
\hline
\end{tabular}

\section{Data analyses}

The relative abundance of each species at each sampling site was estimated by: $P_{j k}=N_{j k} / N_{k}$, where $N_{j k}=$ the number of species $j$ collected in site $k$; $N_{k}=$ the total number of all fishes collected in site $k$. The Margalef index $(D)$ and Shannon-Wiener index $(H)$ were used to calculate fish species richness for each site (Peet 1974; Magurran 1988): $D_{k}=\left(S_{k}-1\right) / \ln N_{k}$ and $H_{k}=-\sum P_{j k} \ln P_{j k}$, where $S_{k}=$ the total number of species collected in site $k$.

\section{Results and Discussion}

\section{Stream characteristics and physico-chemical parameters}

Physico-chemical characteristics were similar across all studied sites in the JNNR. Most of surveyed sampling sites were composed of sandy, gravel and pebble substrates and the banks were lined by boulders and rocks. Shallow pools and riffles alternated in the segments studied. Generally, most mountain streams had clear water and were shaded by riparian vegetation or forest canopy. This appearance is typical of undisturbed forest streams at higher altitudes (Table 1). All sampling sites were fully saturated with dissolved oxygen (mean $\pm \mathrm{SE}, 9.6 \pm 1.2 \mathrm{mgL}^{-1}$ ) and water temperature ranged from $9.0^{\circ} \mathrm{C}$ to $19.8^{\circ} \mathrm{C}$. The high dissolved oxygen levels could be attributed to low water temperature and high flow speed.

\section{Fish fauna}

A total of 553 specimens were collected and classified into 38 species and 12 families in the JNNR. Cyprinidae (17 species, $44.7 \%$ of the total number of fish species collected) were the dominant family, followed by Bagridae (five species, 13.2\%), Homalopteridae (four species, $10.5 \%$ ), Cobitidae (three species, 7.9\%), Gobiidae (two species, 5.3\%) while Siluridae, Amblycipitidae, Sisoridae, Synbranchidae, Serranidae, Odontobutidae and Mastacembelidae were represented by only one species, respectively (Table 2). Overall, 16 species $(42.1 \%$ of the total number of fish species collected in the JNNR) were found to be endemic to China. Endemic fishes were classified into six families. The dominant family of endemic fishes was Cyprinidae (six species) and the subdominant families were Homalopteridae (four species) and Bagridae (three species), while Gobiidae, Amblycipitidae and Odontobutidae were represented by only one species, respectively (Table 2).

The dominant fish species in the JNNR was Pseudogastromyzon changtingensis tungpeiensis (relative abundance (RA) 30.0\%), followed by Acrossocheilus parallens (RA, 22.6\%), Rhinogobius cliffordpopei (RA, 14.8\%) and Rhinogobius giurinus (RA, 11.6\%). They were anatomically well adapted to living in fast flowing current with clear water and relatively higher dissolved oxygen concentration. For instance, Pseudogastromyzon changtingensis tungpeiensis, Rhinogobius cliffordpopei and Rhinogobius giurinus possess a sucker structure under their body to keep them attached to the substrate in the boundary layer created by the water movement. Generally, they feed on algae growing on the rock as well as on detritus and insects.

The general distribution of fish species collected from the seven rivers in the JNNR is shown in Table 2. The most common species present in all river ecosystems was Acrossocheilus parallens. Four species (Opsariichthys bidens, Zacco platypus, Pseudogastromyzon changtingensis tungpeiensis and Rhinogobius cliffordpopei) appeared in more than $50 \%$ of the studied rivers, 13 species were recorded in 2-3 rivers, while 20 fish species appeared in only one river (Table 2). The comparison of fish communities within the surveyed rivers in the JNNR found highest species diversity in Ninggang River (Table 3).

\section{Factors favouring species richness and} endemism

The results of the present field studies in the JNNR showed that more than $10 \%$ of total fish species and $12.2 \%$ of total endemic species in Jiangxi Province (220 fish species and 131 endemic species; Huang et al. 2011) were collected or found to be distributed in 
Table 2 - Composition and distribution of fish species in the JNNR, Jiangxi, China. ${ }^{*}$ Endemic to China (Huang et al. 2011; FishBase: www.fishbase.org), R. = River.

\begin{tabular}{|c|c|c|c|c|c|c|c|}
\hline \multirow{2}{*}{ Family/species } & \multicolumn{7}{|c|}{ Distribution } \\
\hline & Qixiling R. & Ninggang $R$. & Liuba R. & Xiangzhou R. & Xingzhou R. & \begin{tabular}{|l|} 
Xiaoxidong R. \\
\end{tabular} & Xiankou $\mathbf{R}$ \\
\hline \multicolumn{8}{|l|}{ Cyprinidae } \\
\hline Opsariichthys bidens (Günther, 1873) & + & + & & & & + & + \\
\hline Zacco platypus (Temminck \& Schlegel, 1846) & + & + & & + & + & + & + \\
\hline Acrossocheilus parallens (Nichols, 1931)* & + & + & + & + & + & + & + \\
\hline Onychostoma barbatulum (Pellegrin, 1908)* & & + & & & & & \\
\hline Hemiculter leucisculus (Basilewsky, 1855) & + & + & & & & & \\
\hline Culter alburnus (Basilewsky, 1855) & & + & & & & & \\
\hline Abbottina rivularis (Basilewsky, 1855) & + & + & & & & & \\
\hline $\begin{array}{l}\text { Pseudorasbora parva (Temminck \& Schlegel, } \\
\text { 1846) }\end{array}$ & & + & & & & & \\
\hline Sarcocheilichthys kiangsiensis (Nichols, 1930)* & & 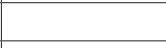 & & & + & & \\
\hline Sarcocheilichthys parvus (Nichols, 1930)* & & + & & & & & \\
\hline $\begin{array}{l}\text { Squalidus argentatus (Sauvage \& Dabry de } \\
\text { Thiersant, 1874) }\end{array}$ & & + & & & + & & \\
\hline Saurogobio dabryi (Bleeker, 1871) & & L & & & + & + & + \\
\hline Rhinogobio typus (Bleeker, 1871)* & & 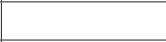 & & & + & & \\
\hline Microphysogobio fukiensis (Nichols, 1926)* & & + & & & & & \\
\hline Hemibarbus labeo (Pallas, 1776) & & + & & & & & \\
\hline Acanthorhodeus chankaensis (Dybowski, 1872) & & + & & & . & & \\
\hline Carassius auratus auratus (Linnaeus, 1758) & & + & & & . & & \\
\hline \multicolumn{8}{|l|}{ Cobitidae } \\
\hline Misgurnus anguillicaudatus (Cantor, 1842) & & + & & & + & + & \\
\hline $\begin{array}{l}\text { Cobitis sinensis (Sauvage \& Dabry de Thier- } \\
\text { sant, 1874) }\end{array}$ & & + & & & & & \\
\hline Schistura incerta (Nichols, 1931) & + & + & & & & & \\
\hline \multicolumn{8}{|l|}{ Homalopteridae } \\
\hline Vanmanenia pingchowensis (Fang, 1935)* & & + & & + & & & \\
\hline Vanmanenia caldwelli (Nichols, 1925)* & & & & & + & & \\
\hline Vanmanenia stenosoma (Boulenger, 1901)* & & & & & + & & \\
\hline $\begin{array}{l}\text { Pseudogastromyzon changtingensis tungpeiensis } \\
\text { (Chen \& Liang, 1949)* }\end{array}$ & + & + & & + & + & & \\
\hline \multicolumn{8}{|l|}{ Siluridae } \\
\hline Silurus asotus (Linnaeus, 1758) & & + & + & & & & \\
\hline \multicolumn{8}{|l|}{ Bagridae } \\
\hline Tachysurus fulvidraco (Richardson, 1846) & & + & & & & & \\
\hline Pelteobagrus ussuriensis (Dybowski, 1872) & & & & & + & & \\
\hline Pseudobagrus pratti (Günther, 1892)* & & & & & & & + \\
\hline Pseudobagrus ondon (Shaw, 1930)* & & + & & + & + & & \\
\hline Hemibagrus macropterus (Bleeker, 1870)* & & + & & & & & \\
\hline \multicolumn{8}{|l|}{ Amblycipitidae } \\
\hline Liobagrus anguillicauda (Nichols, 1926)* & + & & & & & & \\
\hline \multicolumn{8}{|l|}{ Sisoridae } \\
\hline Glyptothorax sinensis (Regan, 1908) & & + & & & & + & + \\
\hline \multicolumn{8}{|l|}{ Synbranchidae } \\
\hline Monopterus albus (Zuiew, 1793) & & + & & & + & & \\
\hline \multicolumn{8}{|l|}{ Serranidae } \\
\hline Siniperca chuatsi (Basilewsky, 1855) & & + & & & & & \\
\hline \multicolumn{8}{|l|}{ Gobiidae } \\
\hline Rhinogobius giurinus (Rutter, 1897) & & + & & & + & & \\
\hline Rhinogobius cliffordpopei (Nichols, 1925)* & & + & & & + & + & + \\
\hline \multicolumn{8}{|l|}{ Odontobutidae } \\
\hline $\begin{array}{l}\text { Odontobutis sinensis (Wu, Chen \& Chong, } \\
\text { 2002)* }\end{array}$ & & + & & & + & & \\
\hline \multicolumn{8}{|l|}{ Mastacembelidae } \\
\hline Sinobdella sinensis (Bleeker, 1870) & & + & & & & & \\
\hline
\end{tabular}


Table 3 - Comparison of fish species diversity and abundance within the rivers, JNNR, China. R. = River.

\begin{tabular}{|l|r|r|r|r|r|r|r|}
\hline & Qixiling R. & Ninggang R. & Liuba R. & Xiangzhou R. & Xingzhou R. & Xiaoxidong R. & Xiankou R. \\
\hline Total number of species (S) & 8 & 30 & 2 & 5 & 16 & 7 & 7 \\
\hline Total number of individuals (N) & 48 & 280 & 20 & 74 & 85 & 29 & 17 \\
\hline Margalef diversity index (D) & 1.81 & 5.15 & 0.33 & 0.92 & 3.37 & 1.78 & 2.12 \\
\hline Shannon-Wiener diversity index (H) & 2.32 & 2.62 & 0.47 & 1.06 & 2.40 & 1.39 & 1.52 \\
\hline
\end{tabular}

mountain streams. The more abundant species or endemic species collected in the JNNR may be partially due to habitat stability and lack of disturbances, such as introduction of exotic species. The riparian zones of streams in the JNNR were densely wooded so that stream temperatures rarely reached $20^{\circ} \mathrm{C}$, even during summer, and dissolved oxygen levels were high at all sites, providing suitable environmental conditions for these fishes.

\section{Current threats and conservation}

In recent decades, streams and rivers in China have been drastically modified because agricultural activities, drinking water provision and the construction of multi-purpose dams, artificial reservoirs, levees, and weirs (Fu et al. 2003). These factors have severely diminished effective migration for those species that move between different stream habitats. Small and fast-flowing streams have often been changed in to large slow-flowing streams. This change means that the organisms become restricted to mountain areas and are replaced by others adapted to slow-flowing streams (Hu et al. 2009). In the JNNR, dams were built on some mountain streams such as the Liuba River. Meanwhile the water of Liuba River had been polluted by the tungsten ore mining in the area (Luo et al. 2002). So relatively low fish species richness was present in the river (Table 3). In addition, some people catch fish for food in the mountain streams of the JNNR using rotenone and other poisons which usually are used to exterminate snails. This kind of fishing not only contributes to reducing fish biodiversity but is also harmful to human health.

Therefore, the primary objective for successful conservation of the freshwater fish species richness in the JNNR must be to develop effective controls and management practices that enable life cycle success, dispersal and population maintenance within stream systems. It is necessary to improve effective fish passage facilities in order to enhance the connectivity of streams for fish dispersal and migration. Fishing activities in the JNNR, especially using rotenone and other poisons must be strictly prohibited. The present study agrees with the statement that long-term management and conservation of the fish fauna of nature reserves and other protected areas in Jiangxi Province will require good bench-mark sites and a long-term monitoring protocol (Jang et al. 2003).

\section{Acknowledgments}

The study was funded by the National Natural Science Foundation of China (No. 31360118), the Natural Science Foundation of Jiangxi Province (No. 20122BAB214020) and the Education Foundation of Jiangxi Province (No. GJJ13090). We are grateful to the staff of the JNNR management station for their help provided during the survey.

\section{References}

Bruton, M.N. 1995. Have fishes had their chip? The dilemma of threatened fishes. Environmental Biology of Fishes 43: 1-27.

Chen, Y.Y. (ed.) 1998. Fauna Sinica: Osteichthyes Cypriniformes II. Beijing (in Chinese).

Cheng, Y., Y.X. Song, J. Zhao, Y.L. Zheng \& G.F. Cui 2011. Investigation and analysis of bird resources in Jinggangshan National Nature Reserve, Jiangxi Province. Sichuan Journal of Zoology 30 (2): 277-282 (in Chinese).

Chu, X.L., B.S. Zheng \& D.Y. Dai (eds.) 1999. Fauna Sinica: Osteichthyes Siluriformes. Beijing (in Chinese).

Deng, X.L., Y.C. Liu \& Y. Wu 2003. Interconnection among dominant plant populations of Castanopsis community in Jinggang mountain nature reserve. Acta Phytoecologica Sinica 27 (4): 531-536 (in Chinese).

Deng, X.L., W.W. Long, D.F. Xu, Y.C. Liu \& D.S. Chen 2008. Studies on Fokienia hodginsii community in Jinggangshan nature reserve. Journal of Tropical and Subtropical Botany 16 (2): 128-133 (in Chinese).

Duncan, J.R. \& J.L. Lockwood 2001. Extinction in a field of bullets: a search for the causes in the decline of the world's freshwater fishes. Biological Conservation 102: 97-105.

Fu, C.Z., J.H. Wu, J.K. Chen, Q.H. Wu \& G.C. Lei 2003. Freshwater fish biodiversity in the Yangtze River basin of China: patterns, threats and conservation. Biodiversity and Conservation 12: 1649-1685.

Hu, M.L., Z.Q. Wu \& Y.L. Liu 2009. The fish fauna of mountain streams in the Guanshan National Nature Reserve, Jiangxi, China. Environmental Biology of Fishes 86: 23-27.

Huang, L.L., Z.Q. Wu \& J.H. Li 2011. Fish fauna, biogeography and conservation of freshwater fish in Poyang Lake Basin, China. Environmental Biology of Fishes. doi: 10.1007/s10641-011-9806-2.

Huang, Z.H., Y.Z. Song, C.Q. Chen, J. Long \& Y. Xiao 2007a. Diversity of reptiles in Jinggangshan Na- 
tional Nature Reserve. Sichuan Journal of Zoology 26 (2): 368-369 (in Chinese).

Huang, Z.H., H.Q. Wu, D. Chen, Y.Z. Song, C.Q. Chen \& C.X. Zuo 2007b. Amphibian diversity and conservation in Jinggangshan Nature Reserve. Jiangxi Science 25 (5): 643-647 (in Chinese).

Jang, M.H., C.L. Martyn \& G.J. Joo 2003. The fish fauna of mountain streams in South Korean national parks and its significance to conservation of regional freshwater fish biodiversity. Biological Conservation 114: $115-126$

Li, X.H., Y. Xiao, W.W. Long, W.H. Hu \& Y. Wu 2005. Study on species diversity of Rhododendron fortunei community in Jinggangshan nature reserve. Journal of Zhejiang Forestry Science and Technology 25 (1): 17-20 (in Chinese).

Lin, Y. 1990. Scientific survey and research on the Jinggangshan Nature Reserve. Beijing (in Chinese).

Long, W.W., X.L. Deng \& C.X. Zuo 2008. Floristic analysis of taxus mairei community in Jinggangshan nature reserve. Journal of Anbui Agricultural Sciences 36 (5): 1840-1842 (in Chinese).

Luo, L.S. \& B.H. Li 2002. Study on the exploitation and utilization of mineral resources in Jinggangshan district. Territory and Natural Resources Study (3): 58-59 (in Chinese).

Magurran, A.E. (ed.) 1988. Ecological diversity and its measurement. London.

Moyle, P.B. \& R.A. Leidy 1992. Loss of biodiversity in ecosystems: evidence from fish faunas. In: Fiedler, P.L. \& S.K. Jain (eds.), Conservation biology: the theory and practice of nature conservation, preservation and management. New York: 127-169.

Peet, R.K. 1974. Measurement of species diversity. Annual Review of Ecology and Systematics 5: 285-307.

Xiao, Y., P. He, X.H. Li, M.Z. Shi \& W.H. Hu 2004. Studied on the pteridophytes resources in Jinggang- shan Nature Reserve. Bulletin of Botanical Research 24 (1): 35-40 (in Chinese).

Yue, P.Q. (ed.) 2000. Fauna Sinica: Osteichthyes Cypriniformes III. Beijing (in Chinese).

Zhu, S.Q. (ed.) 1995. The synopsis of freshwater fishes of China. Nanjing (in Chinese).

Zuo, C.X., J.Q. Wang, W.J. Guo, W.Y. Liu, F.H. Jia \& Z.J. Shi 2008. Butterfly resource of Jinggangshan National Nature Reserve in Jiangxi Province. Entomological Journal of East China 17 (3): 220-225 (in Chinese).

\section{Authors}

Maolin $\mathrm{Hu}$

School of Life Sciences and Food Engineering, Nanchang University, Nanchang, Jiangxi Province, 330031, P.R. China. Contact: humaolin@ncu.edu.cn

\section{Huiming Zhou}

Jiangxi Fisheries Research Institute, Nanchang, Jiangxi Province, 330039, P.R. China

\section{Zhiqiang Wu}

College of Environmental Science and Engineering, Guilin University of Technology, Guilin, Guangxi Zhuang Autonmous Region, 541004, P.R. China

\section{Shan Ouyang}

School of Life Sciences and Food Engineering, Nanchang University, Nanchang, Jiangxi Province, 330031, P.R. China

\section{Chunquan Chen}

Administration of Jiangxi Jinggangshan National Nature Reserve, Jinggangshan, Jiangxi Province, 343600, P.R. China 